\title{
Alternative device structures for CIGS-based solar cells with semi-transparent absorbers
}

\author{
Kihwan $\mathrm{Kim}^{1,2}$ and William N. Shafarman ${ }^{2}$ \\ ${ }^{1}$ Photovoltaic laboratory, Korea Institute of Energy Research, Daejeon 34129, Republic of Korea \\ ${ }^{2}$ Institute of Energy Conversion, University of Delaware, Newark, DE 19716, USA
}

\begin{abstract}
In this work, we discuss two alternative structures of CIGS-based solar cells, a bi-facial configuration and a back-wall configuration. One of the critical issues in these structures is fabrication of a transparent back contact which facilitates not only ohmic contact for holes in the valance but also an effective reflector for electrons in the conduction band. In order to meet these requirements of the transparent back contact, a p-type amorphous $\mathrm{Si}(\mathrm{p}$-a-Si)/intrinsic amorphous $\mathrm{Si}$ (i-a-Si) bi-layer was deposited onto the ITO back contact. Absorber films were formed by a metal precursor reaction in $\mathrm{H}_{2} \mathrm{Se}$ and $\mathrm{H}_{2} \mathrm{~S}$, and their thicknesses were adjusted to about $0.25 \mu \mathrm{m}$ to enhance current collection from back-side illumination. The resulting devices with a bi-facial structure of $\mathrm{SLG} / \mathrm{ITO} / \mathrm{p}-\mathrm{Si} / \mathrm{i}-\mathrm{Si} / \mathrm{Cu}(\mathrm{In}, \mathrm{Ga})(\mathrm{Se}, \mathrm{S})_{2} / \mathrm{CdS} / \mathrm{i}-\mathrm{ZnO} / \mathrm{ITO} / \mathrm{Ni}-\mathrm{Al}$ exhibited a comparable open-circuit voltage to a $\mathrm{Cu}(\mathrm{In}, \mathrm{Ga})(\mathrm{Se}, \mathrm{S})_{2}$ cell on a Mo substrate in tests with illumination of both sides. Back-wall cells with a structure of $\mathrm{SLG} / \mathrm{ITO} / \mathrm{p}-\mathrm{Si} / \mathrm{i}-\mathrm{Si} / \mathrm{Cu}(\mathrm{In}, \mathrm{Ga})(\mathrm{Se}, \mathrm{S})_{2} / \mathrm{CdS} / \mathrm{i}_{-}$ $\mathrm{ZnO} / \mathrm{Ag}$-reflector were also fabricated and improved current collection by greater light trapping was achieved compared to the bi-facial cell with back-side illumination.
\end{abstract}

Keywords: CIGS, Solar Cells, ultra thin, bi-facial, semi-transparent,selenization 


\section{Introduction}

$\mathrm{Cu}(\mathrm{In}, \mathrm{Ga}) \mathrm{Se}_{2}$ (CIGS; when S included, CIGSS)-based materials have gained marked attention for thin-film photovoltaic applications due to their high absorption coefficient, tunable bandgap, compositional tolerance, outstanding stabilities, and high efficiency [1]. It is notable that a 22.6\%-efficient cell has been demonstrated by ZSW and it seems to be one of the most efficientcompound materials which are able to accommodate mass-manufacturing [2]. Typically, CIGS absorber layers are formed on the Mo-coated soda-lime glass (SLG) by numerous methods such $\underline{\text { as co-evaporation, metal precursor reaction or particle synthesis, etc [3-5]. Then, a CdS buffer }}$ layer (sometimes, Zn- or In-based buffer) is deposited for various purposes: to avoid a large $\underline{\text { lattice mismatch between CIGS and TCO, and to protect a damage from subsequent processes [1, }}$ 6]. As a result, conventional CIGS modules have a substrate configuration of $\underline{\text { SLG/Mo/CIGS/CdS/TCO and thus another cover glass is necessary to protect the modules. }}$

As low cost production of CIGS solar cells becomes a primary requisite for successful competition with conventional Si-based solar cells, reducing process time and raw materials have gained increasing attention [7-10]. Among several approaches, a superstrate (i.e. glass/TCO/buffer/CIGS/back contact) [11] or back-wall configuration (i.e. glass/transparent back

contact (TBC)/CIGS/buffer/front contact) [12] is a promising method to meet the demand for cost reduction since it can allow saving glass usage by replacing with a low-cost opaque back sheet film as in typical Si modules [13]. Also, due to reduced number of glass sheets, modules have lighter weight compared to a conventional CIGS module. Furthermore, adopting TBC in the CIGS solar cells offers extra benefits: 1) successful formation of CIGS/TBC can be used to a 
CIGS-based tandem solar cell, since a top CIGS subcell must have a TBC for allowing light transmission for a bottom subcell. 2) If a CIGS absorber is thin enough to be semi-transparent, it can be employed in window applications capable of capturing of energy in vehicles or buildings.

Only a small number of works concerning superstrate-configured CIGS solar cells have been reported [11, 14, 15]. Development of CIGS-based solar cells with a superstrate configuration yields a different set of critical issues than the substrate configuration: (1) Junction degradation during high temperature deposition of the absorber onto the buffer [16] and (2) identification of a suitable back electrode [11]. Using a glass/ITO/CdS/CIGS/Pt structure, an efficiency of $6.6 \%$ has been previously achieved from $0.4 \mu \mathrm{m}$ thick CIGS absorber [17]. It, however, also appeared that performance was limited in part by interdiffusion of the $\mathrm{CdS} / \mathrm{CuInSe}_{2}$ interface due to high $\mathrm{CuInSe}_{2}$ growth temperature. Nakada et al. reported a $12.8 \%$ efficiency by eliminating the $\mathrm{CdS}$ to form a $\mathrm{ZnO} / \mathrm{CIGS}$ junction. Reaching this efficiency required control of the Ga gradient and Na content in the CIGS in combination with light soaking [11].

Interestingly, a back-wall CIGS cell configuration has not frequently been attempted in spite of one great advantage, which is a controlled CdS/CIGS junction formation like in a substrate cell since a CdS layer is deposited after CIGS formation. In this configuration two key issues should be addressed: (1) the absorber layer should be thin enough so that light absorption occurs in vicinity of the junction for efficient charge collection and (2) a TBC with a relatively high work function should be employed to form an ohmic contact and, at the same time, to prevent interface recombination at the CIGS/TBC interface [18]. For instance, $\mathrm{MoO}_{3}$ interlayers can be used for the same purpose $[12,19-21]$ since $\mathrm{MoO}_{3}$ has a sufficiently high work function of $5.5 \mathrm{eV}$ and 
high light transmission [22]. In particular, with our previous work [12], back-wall CIGS solar cells with $\mathrm{MoO}_{3}$ turned out to exhibit $8.3 \%$. With thin absorber $(\sim 0.3 \mu \mathrm{m})$ and enhanced light trapping technique, we have demonstrated the potential of this device configuration.

In this work, we demonstrate bi-facial and back-wall CIGSS solar cells with a thin absorber layer on SLG/ITO/p-type amorphous $\mathrm{Si}$ (p-a-Si)/intrinsic amorphous $\mathrm{Si}$ (i-a-Si). The potential of the pa-Si/i-a-Si bilayer is an electronically controllable material, and its growth techniques (typically, chemical vapor deposition) are fairly common and reproducible. With metal precursor reaction in $\mathrm{H}_{2} \mathrm{Se}$ or $\mathrm{H}_{2} \mathrm{~S}, 0.25 \mu$ m-thick CIGSS absorber layers were formed and then bi-facial CIGSS solar cells were fabricated with the device structure: SLG/ITO/p-Si/i-Si/Cu(In,Ga)(Se,S) $2 / \mathrm{CdS} / \mathrm{i}-$ ZnO/ITO/Ni-Al. Back-wall CIGSS cells with the structure of SLG/ITO/p-Si/i-Si/CIGSS/CdS/i$\mathrm{ZnO} / \mathrm{Ag} / \mathrm{Al}$ were fabricated to enhance light absorption but utilization of a $\mathrm{Ag}$ reflector. $\underline{\text { In this }}$ configuration, electrons are directly collected at the Ag reflector and thus a top TCO can be omitted. 


\section{Experimental}

Two kinds of substrates, SLG/ITO (200nm) and SLG/ITO (200 nm)/p-type amorphous Si (p-a-Si, $10 \mathrm{~nm}$ )/intrinsic amorphous $\mathrm{Si}(\mathrm{i}-\mathrm{a}-\mathrm{Si}, 10 \mathrm{~nm}$ ), were used in this study. The ITO films were prepared by sputtering of an ITO target. The p-a-Si/i-a-Si bi-layer was grown with plasmaenhanced chemical vapor deposition (PECVD) with $\mathrm{SiH}_{4}$. In case of the p-a-Si, mixed gas of $\mathrm{B}_{2} \mathrm{H}_{6}$ and $\mathrm{SiH}_{4}$ gas was also added into the reaction. The details of the a-Si film deposition are available in literature [23].

Cu-In-Ga metal precursors were deposited on SLG/Mo, SLG/ITO and SLG/ITO/p-a-Si/i-a-Si substrates by co-sputtering from $\mathrm{Cu}_{0.77} \mathrm{Ga}_{0.23}$ and In targets. Alternating thin layers of $\mathrm{CuGa}$ and In were repeatedly deposited in rotation until a desirable thickness was reached. The deposited precursors were found to have $\mathrm{Ga} /(\mathrm{Ga}+\mathrm{In}) \approx 0.26$ and $\mathrm{Cu} /(\mathrm{Ga}+\mathrm{In}) \approx 0.91$ by $\mathrm{X}$-ray fluorescence (XRF).

Metal precursors were reacted at atmospheric pressure in a 2" diameter tubular reactor using a three-step process. First, the selenization reaction was performed under flowing $\mathrm{H}_{2} \mathrm{Se}(0.35 \%) / \mathrm{O}_{2}(0.0035 \%) / \mathrm{Ar}$ (Balance) (1st step) at $400^{\circ} \mathrm{C}$ for $5 \mathrm{~min}(0.25 \mu \mathrm{m}$-thick CIGSS) or $50 \min \left(2 \mu \mathrm{m}\right.$-thick CIGSS). Then, the temperature was ramped up to $550^{\circ} \mathrm{C}$ and the samples were annealed for 20 min under Ar atmosphere (2nd step). Finally, sulfization at $550^{\circ} \mathrm{C}$ was performed with $\mathrm{H}_{2} \mathrm{~S}(0.35 \%) / \mathrm{O}_{2}(0.0035 \%) / \mathrm{Ar}$ (balance) (3rd step) for $5 \mathrm{~min}(0.25 \mu \mathrm{m}$-thick CIGSS) or 50 min ( $2 \mu \mathrm{m}$-thick CIGSS). The times of selenization and sulfization were adjusted 
to yield homogenized Ga composition, reasonable film adhesion, and controlled $\mathrm{S}$ incorporation based on the thickness of metal precursors.

Solar cells were also fabricated with structures of SLG(1.7 mm)/Mo( $500 \mathrm{~nm}) / \mathrm{CIGSS}(0.25 \mu \mathrm{m}) /$ $\mathrm{CdS}(50 \sim 60 \mathrm{~nm}) / \mathrm{i}-\mathrm{ZnO}(50 \mathrm{~nm}) / \mathrm{ITO}(100 \mathrm{~nm}) / \mathrm{Ni}(5 \mathrm{~nm}) / \mathrm{Al}(2 \mu \mathrm{m})$ (i.e. a conventional structure), $\operatorname{SLG}(1.7 \mathrm{~mm}) / \mathrm{ITO}(200 \mathrm{~nm}) / \operatorname{CIGSS}(0.25 \mu \mathrm{m}) / \mathrm{CdS}(50 \sim 60 \mathrm{~nm}) / \mathrm{i}-\mathrm{ZnO}(50 \mathrm{~nm}) / \mathrm{ITO}$ (100 $\mathrm{nm}) / \mathrm{Ni}(5 \mathrm{~nm}) / \mathrm{Al}(2 \mu \mathrm{m})$, and SLG(1.7 mm)/ ITO(200 nm)/p-Si(10 nm)/i-Si $(10 \mathrm{~nm}) / \mathrm{CIGSS}$ $(0.25 \mu \mathrm{m}) / \mathrm{CdS}(50 \sim 60 \mathrm{~nm}) / \mathrm{i}-\mathrm{ZnO}(50 \mathrm{~nm}) / \mathrm{ITO}(200 \mathrm{~nm}) / \mathrm{Ni}(5 \mathrm{~nm}) / \mathrm{Al}(2 \mu \mathrm{m})$, and their J-V characteristics and spectral responses were investigated. To fabricate a back-wall CIGSS cell with enhanced light trapping, cells with a structure of SLG $(1.7 \mathrm{~mm}) / \mathrm{ITO}(200 \mathrm{~nm}) / \mathrm{p}-\mathrm{Si}(10$ $\mathrm{nm}) / \mathrm{i}-\mathrm{Si}(10 \mathrm{~nm}) / \mathrm{CIGSS}(0.25 \mu \mathrm{m}) / \mathrm{CdS}(50 \sim 60 \mathrm{~nm}) / \mathrm{i}-\mathrm{ZnO}(50 \mathrm{~nm}) / \mathrm{Ag}(100 \mathrm{~nm}) / \mathrm{Al}(2 \mu \mathrm{m})$ were made, in which the top ITO layer was omitted and the Ag top reflector was formed instead. 


\section{Results and discussion}

\section{a) Bi-facial CIGSS cells on SLG/ITO/Si bi-layer substrates}

First, effects of absorber thickness with Mo back contact are discussed in Fig. 1. Fig. 1(a) shows J-V characteristics of CIGSS (on Mo) solar cells with the two thicknesses. It should be noted that the device characteristics were found to be relatively well-maintained in the $0.25 \mu \mathrm{m}$-thick CIGSS absorber when comparing to the $1.9 \mu \mathrm{m}$ counterpart. There is no significant difference in $\mathrm{V}_{\mathrm{OC}}$ and fill factor (FF). The primary loss of the $0.25 \mu \mathrm{m}$-thick CIGSS cell is a decrease in $\mathrm{J}_{\mathrm{SC}}$ which amounts to $68 \%$ of $1.9 \mu$ m-thick CIGSS cell. The loss of $\mathrm{J}_{\mathrm{SC}}$ is slightly greater than the expected reduction (approximately 25\%) due to incomplete optical absorption [1]. The obtained results suggest that the CIGSS cells exhibit less sensitivity to absorber thickness compared to previous studies [7, 8]. The spectral responses of the two devices are shown in Fig. 1(b). Compared with the control $(1.9 \mu \mathrm{m}$-thick CIGSS cell), the $0.25 \mu \mathrm{m}$-thick CIGSS cell exhibits significant loss above $600 \mathrm{~nm}$, primarily due to incomplete photon absorption. The details of the reduced CIGSS thickness has been discussed in our previous work [9].

There are two key requirements for making an efficient bi-facial or back-wall CIGSS cell. First, a transparent back contact (TBC) should be employed to allow light-transmission. Second, the junction should be located in the vicinity of the TBC. In order to meet the second criterion, a CIGS (or CIGSS) absorber should be thinner than a typical thickness of $1.5 \sim 2 \mu \mathrm{m}$. Otherwise, current collection and open circuit voltage may be limited since this structure has a greater possibility for losing charge carriers formed near the TBC. Thus, $0.25 \mu \mathrm{m}$-thick CIGSS 
absorbers with the three-step $\mathrm{H}_{2} \mathrm{Se} / \mathrm{Ar} / \mathrm{H}_{2} \mathrm{~S}$ reaction have been used as absorbers of bi-facial or back-wall CIGSS cells in the present study.

Fig. 2 shows the J-V characteristics (a) and band diagram (b) of a CIGSS cell with SLG/ITO/CIGSS $(0.25 \mu \mathrm{m}) / \mathrm{CdS} / \mathrm{ZnO} / \mathrm{ITO} / \mathrm{Ni}-\mathrm{Al}$, in which a $200 \mathrm{~nm}$-thick ITO was employed as the TBC. The cell was illuminated from the top surface (i.e. substrate configuration). Interestingly, the CIGSS cell with the ITO back contact turned out to exhibit a strong shunting behavior. The band diagram in Fig. 2 (b) suggests there is little band bending in the CIGSS bulk due to back-to-back junction formations at the CdS/CIGSS and CIGSS/ITO interfaces. In this band alignment, electrons flow easily in any direction and thus the device exhibits severe shunting behavior. Not shown here, simulated J-V characteristics also turned out to have a strong shunting (more details are available in the supplementary information). In typical CIGS cells, a thin $\mathrm{MoSe}_{2}$ layer is naturally formed on top of the Mo back contact and may help to prevent the electron loss at the CIGS (or CIGSS)/Mo interface by building up an energy barrier in the contact band $[24,25]$. The shunting behavior strongly suggests that a band-alignment should be modified by inserting an interlayer which can act in the role of $\mathrm{MoSe}_{2}$.

To prevent the shunting behavior of a bi-facial CIGSS cell with a sub-micron absorber, a p-a$\mathrm{Si} / \mathrm{i}-\mathrm{a}-\mathrm{Si}$ bi-layer (Si bi-layer) was inserted between ITO and CIGSS in an attempt to create an electron blocking barrier (EBL). The doping concentration of the p-a-Si layer is about $2 * 10^{19} \mathrm{~cm}^{-}$ ${ }^{3}$ [23], and it can help to reduce the CIGSS band bending induced by the n-type ITO. The role of the i-a-Si layer is to reduce stiff band bending in the a-Si layer. Therefore, a thicker energy barrier for electrons in the i-a-Si layer can be formed and it may help to reduce the tunneling of 
electrons from the CIGSS to the Si bi-layer. The electron affinity of CIGS $\left(\mathrm{E}_{\mathrm{g}} \sim 1.15 \mathrm{eV}\right)$ is about $4.5 \mathrm{eV}$ [26], while a-Si has an electron an affinity of $3.8 \mathrm{eV}$ and a bandgap of $1.7 \mathrm{eV}$ [27]. Fig. 3 depicts a band alignment between CIGS and p-a-Si. A conduction band offset (i.e. $\Delta \mathrm{E}_{\mathrm{C}}$ ) is given by the following relation:

$$
\Delta E_{C}=\Delta \chi=\chi_{C I G S}-\chi_{a-S i}
$$

where, $\chi$ is electron affinities of each element. $\mathrm{A} \Delta \mathrm{E}_{\mathrm{C}}$ of $0.7 \mathrm{eV}$ is obtained. Meanwhile, the valence band offset $\Delta \mathrm{E}_{\mathrm{V}}$ of hetrojunction is given by,

$$
\Delta E_{V}=\Delta E_{G}-\Delta \chi=\left(E_{a-S i}-E_{C I G S}\right)-\left(\chi_{C I G S}-\chi_{a-S i}\right)
$$

If the same values are used, a $\Delta \mathrm{E}_{\mathrm{V}}$ of $-0.15 \mathrm{eV}$ is obtained. Since the Fermi level $\mathrm{E}_{\mathrm{F}}$ of the $\mathrm{p}-\mathrm{a}-\mathrm{Si}$ typically lies about $0.3 \mathrm{eV}$ above its $\mathrm{E}_{\mathrm{V}}[23]$, the $\Delta \varphi_{\mathrm{b}}\left(=\varphi_{\mathrm{p}-\mathrm{a}-\mathrm{Si}}-\varphi_{\mathrm{CIGS}}, \varphi\right.$ denotes the work function of material) in Fig. 3 is approximately $-0.4 \mathrm{eV}$. In this band alignment, hole transport might be slightly hindered by the energy barrier of about $-0.4 \mathrm{eV}$ (i.e. $\Delta \varphi_{\mathrm{b}}$ ), and therefore a CIGSS device with the ITO/p-a-Si/i-a-Si substrate is expected to have a greater series resistance compared to a CIGS cell on Mo. In principle, further increase in the doping concentration of $\mathrm{p}$-a$\underline{\text { Si appears to be beneficial in terms of career transport through the CIGSS/TBC interface by }}$ narrowing the energy barrier of holes (i.e. $\Delta \varphi_{\mathrm{b}}$ ). However, in this work, the doping concentration was controlled within ensuring a process reproducibility. In addition, excessively high doping concentration could also allow the tunneling of electrons through the CIGSS/TBC interface. 
The three-step $\mathrm{H}_{2} \mathrm{Se} / \mathrm{Ar} / \mathrm{H}_{2} \mathrm{~S}$ reaction involves procedures at $550{ }^{\circ} \mathrm{C}$ and thus the a-Si bi-layer can be partially crystallized. Thus, Raman analysis has been carried out on the Si bi-layer after delaminating the CIGSS film to expose the Si bi-layer. Fig. 4 shows Raman spectra before (a)

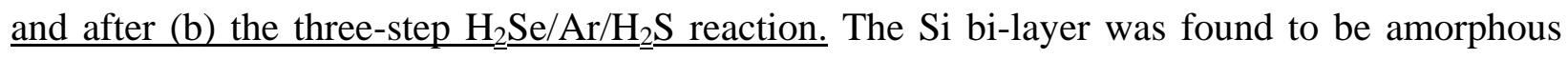
before the reaction. However, after the three-step $\mathrm{H}_{2} \mathrm{Se} / \mathrm{Ar} / \mathrm{H}_{2} \mathrm{~S}$ reaction the a-Si layer turned out to be partially crystallized and giving rise to a sharp peak corresponding to crystalline Si was found at $517.4 \mathrm{~cm}^{-1}$. The peak shift with respect to mono-crystalline $\mathrm{Si}$ is found to be $2.7 \mathrm{~cm}^{-1}$, suggesting the mean crystallite size and volume fraction of crystalline $\mathrm{Si}$ are approximately $8 \mathrm{~nm}$ and $14 \%$, respectively $[28,29]$. The a-Si bi-layer does not completely crystallize during the three-step $\mathrm{H}_{2} \mathrm{Se} / \mathrm{Ar} / \mathrm{H}_{2} \mathrm{~S}$ reaction. Since the $\mathrm{Si}$ bi-layer includes some crystalline-Si (c-Si), it is called the p-type Si/intrinsic Si (p-Si/i-Si) bi-layer hereafter. Crystalline-Si (or poly-Si) has a bandgap of about $1.1 \mathrm{eV}$ and an electron affinity of $4.1 \mathrm{eV}$, and therefore $\Delta \mathrm{E}_{\mathrm{C}}$ is likely to be about $0.4 \mathrm{eV}$. The $\Delta \mathrm{E}_{\mathrm{C}}$ value becomes smaller; however, since the volume fraction of crystalline Si is only about $14 \%$, it may have a limited effect on the J-V characteristics.

Fig. 5(a) and (b) show a schematic drawing and cross-sectional SEM image of a complete CIGSS cell with a p-Si(10 nm)/i-Si(10 nm) bi-layer. The growth of CIGSS does not seem to be significantly affected by the $\mathrm{p}-\mathrm{Si} / \mathrm{i}-\mathrm{Si}$ bi-layer and its microstructure is nearly identical to the CIGSS film on the Mo contact ( see Ref. [9] ). A photo of the complete cell is shown in Fig. 5(c). Due to the thin absorber thickness, the cell still exhibits some degree of transparency. UVvisible-IR transmittance analysis revealed that up to $9 \%$ of the photons in visible region pass through the entire cell (refer to the supplementary information). 
Light J-V curves of the bifacial CIGSS cell with ITO/p-Si/i-Si back contact are shown in Fig. 6(a). The light J-V curve from the front-side illumination (red) reveals the cell has an efficiency of $6.5 \%$ with $\mathrm{V}_{\mathrm{OC}}$ of $598 \mathrm{mV}$ and $\mathrm{J}_{\mathrm{SC}}$ of $22.9 \mathrm{~mA} / \mathrm{cm}^{2}$. It is worthwhile to note that the $\mathrm{V}_{\mathrm{OC}}$ of the cell is nearly identical to a CIGSS cell on the Mo back contact (Fig. 1), which is an identification that the p-Si/i-Si bi-layer could play the role of EBL. However, the fill factor is lower than that of the cell on the Mo back contact. A mild slope of the $\mathrm{J}-\mathrm{V}$ curves above $0.5 \mathrm{~V}$ is ascribed to a high series resistance $\left(\mathrm{R}_{\mathrm{s}} \sim 8 \Omega \mathrm{cm}^{2}\right)$ presumably due to the unfavorable valence band alignment (i.e. $\Delta \varphi_{\mathrm{b}}$ in Fig. 3). When tested with illumination from the back (blue), the device exhibits smaller $\mathrm{J}_{\mathrm{SC}}$ compared to the normal testing configuration (i.e. front-side illumination). As will be discussed later, light loss from the $\mathrm{SLG}(1.7 \mathrm{~mm}) / \mathrm{ITO} / \mathrm{p}-\mathrm{Si} / \mathrm{i}-\mathrm{Si}$ is mainly ascribed to lower $\mathrm{J}_{\mathrm{SC}}$ under the back-side illumination.

External quantum efficiency (EQE) curves of both the testing configurations are shown in Fig. 7(a). The reflectance curves of each side are also given with the right $\mathrm{Y}$ axis. The EQE curve of the front-side illumination (solid square) is quite similar to the cell with the Mo back contact described in Fig. 1(b). The EQE curve from the back-side illumination (solid circle) is generally lower than when being tested with the front-side illumination due to parasitic absorption of the $\mathrm{SLG}(1.7 \mathrm{~mm}) / \mathrm{ITO}(200 \mathrm{~nm}) / \mathrm{p}-\mathrm{Si} / \mathrm{i}-\mathrm{Si}$ substrate. It is worthwhile to note that both sides do not have any significant difference in the reflectance. However, the QE from the back-side illumination does not have a strong absorption at $2.4 \mathrm{eV}(516 \mathrm{~nm})$ corresponding to the bandgap of CdS since photons are directly absorbed in the CIGSS bulk without passing the CdS buffer. Fig. 7(b) compares the EQE curve with the back-side illumination (the same one in Fig. 7(a)) and its redrawn one after removing the parasitic light loss from the SLG/ITO/p-Si/i-Si substrate. The 
redrawn curve was obtained by dividing the EQE curve by the transmittance of the SLG/ITO/p-

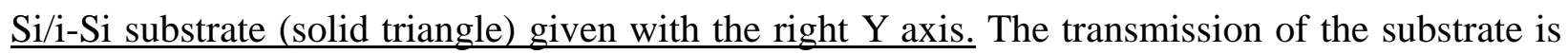
only about $50 \%$ from $600 \mathrm{~nm}$ to $1200 \mathrm{~nm}$, and moreover strong absorption occurs below $500 \mathrm{~nm}$. Since the average light transmission of $\operatorname{SLG}(1.7 \mathrm{~mm}) / \mathrm{ITO}(200 \mathrm{~nm})$ is about $80 \%$ in the range of $500-1200 \mathrm{~nm}$, the light absorption of the Si bi-layer is ascribed to the main reason for the light loss. The quantum efficiency curve without any light loss from the SLG/ITO/p-Si/i-Si (solid square) substrate reveals that current collection occurs in excess of $80 \%$ in the visible light region; however, incomplete absorption still limits the current collection above $800 \mathrm{~nm}$.

\section{b. Back-wall configured CIGSS solar cell with enhanced light absorption}

In order to obtain improved current collection from the back-side illumination, a back-wall CIGSS cell with a silver (Ag) reflector has been demonstrated [12]. A Ag reflector (100 nm) has been formed directly onto the $\mathrm{i}-\mathrm{ZnO}$ layer omitting the ITO film acting the TCO layer in a typical CIGS cell. Fig. 8 shows the J-V curve of the back-wall configured CIGSS cell and the structure of the back-wall configured CIGSS cell is schematically drawn in the inset of Fig. 8 . The $\mathrm{V}_{\mathrm{OC}}$ of this cell is maintained indicating that charge separation is independent on the presence of the TCO layer in a CIGS (or CIGSS) cell. The $\mathrm{J}_{\mathrm{SC}}$ increased compared to the bifacial cell with the back-side illumination as shown in Fig. 6. As mentioned in the previous section, the parasitic absorption in the SLG/ITO/p-Si/i-Si substrate and the un-optimized valence band alignment appeared to be limiting factors in $\mathrm{J}_{\mathrm{SC}}$ and $\mathrm{FF}$, respectively. 
Fig. 9 shows the QE curves of the back-wall CIGSS cell described in Fig. 8. The current collection of the back-wall configured CIGSS cell (solid square) was also improved with about $14 \%$ compared to the bi-facial CIGSS cell with the back-side illumination (solid circle). When excluding the light loss from the $\mathrm{SLG} / \mathrm{ITO} / \mathrm{p}-\mathrm{Si} / \mathrm{i}-\mathrm{Si}$ substrate using the same method as described in Fig. 7(b), the current collection almost completely occurred below $800 \mathrm{~nm}$ due to the light absorption enhancement by the top Ag reflector. However, the EQE above $800 \mathrm{~nm}$ still has a slightly stiff negative slope, suggesting incomplete light absorption and/or back-surface recombination with some extent. First, including reflection at the Ag reflector, the effective thickness for light absorption is about $0.5 \mu \mathrm{m}$ in the back-wall CIGSS cell, and thus the incomplete absorption in the long wavelength region is still expected [9]. Optimization of the thickness of a CIGSS film and/or light trapping techniques may help to improve a current collection in the long wavelength region. Second, even though the ITO/p-Si/i-Si turned out to provide improved J-V characteristics than a typical ITO back contact, further suppression of recombination near the CIGSS/TBC interface appears to be necessary. In such case, localized contact seems to be a way to ensure longer life times of charge carriers [30]. 


\section{Conclusions}

With metal precursor reaction, bi-facial and back-wall CIGS (when S included, CIGSS) solar cells were fabricated and their device performances were investigated. To sucessfully make devices with theses structures this work has focused on sub-micron aborber formation and development of a novel transparent back contact.

To allow light transmission through the back side of cells, an ITO layer was utilized as the back contact of CIGSS cell. CIGSS films were formed by a metal precursor reaction in $\mathrm{H}_{2} \mathrm{Se}$ and $\mathrm{H}_{2} \mathrm{~S}$, and their thicknesses were adjusted to about $0.25 \mathrm{um}$ to enhance current collection from the back-wall configuration. However, CIGSS film formation on the ITO back conact resulted in sereve shunting, suggesting that electrons flows almost freely from the CdS/CIGSS to CIGSS/ITO interface due to weak band-bending.

To suppress the shunting behavior of the CIGSS cell on the transparent back contact, a pamorphous Si (p-a-Si, $10 \mathrm{~nm}$ )/i-amorphous $\mathrm{Si}(\mathrm{i}-\mathrm{a}-\mathrm{Si}, 10 \mathrm{~nm}$ ) bi-layer was introduced between the ITO and CIGSS film. It was hypothesized that the p-a-Si/i-a-Si bi-layer forms an electron barrier, reflecting electrons toward the CIGS/CdS junction preventing the shunting behavior. The resulting devices with a bi-facial structure of $\mathrm{SLG} / \mathrm{ITO} / \mathrm{p}-\mathrm{Si} / \mathrm{i}-\mathrm{Si} / \mathrm{Cu}(\mathrm{In}, \mathrm{Ga})(\mathrm{Se}, \mathrm{S})_{2} / \mathrm{CdS} / \mathrm{i}$ $\mathrm{ZnO} / \mathrm{ITO} / \mathrm{Ni}-\mathrm{Al}$ were found to have a significant improvement in $\mathrm{V}_{\mathrm{OC}}$ from both of front and back illuminations compared to devices on ITO, indicating the junction field of the cells were properly established and the direct shunting was effectively suppressed. Nevertheless, the devices exhibited high series resistance which is tentatively ascribed to an energy barrier for 
holes. A back-wall cell with a structure of $\mathrm{SLG} / \mathrm{ITO} / \mathrm{p}-\mathrm{Si} / \mathrm{i}-\mathrm{Si} / \mathrm{Cu}(\mathrm{In}, \mathrm{Ga})(\mathrm{Se}, \mathrm{S})_{2} / \mathrm{CdS} / \mathrm{i}-\mathrm{ZnO} / \mathrm{Ag}$ reflector was also fabricated to enhance light absorption, in which an ITO layer was omitted. As a result, a greater current collection was obtained than the bi-facial cell with the back side illumination. 


\section{Acknoledgements}

The authors would like to gratefully acknowledge the contributions of Kevin Hart, Dan Ryan and

John Elliot for device fabrication, Ujjwal Das for the deposition of Si films, and Jinwoo Lee and Jes Larsen for valuable discussions. This work was supported by the Foundational Program to Advance Cell Efficiency (F-PACE) funded by the Department of Energy of the USA (No. DEEE0005407) and the International Collaborative Energy Technology R\&D Program of the Korea Institute of Energy Technology Evaluation and Planning (financial source from the Ministry of Trade, Industry \& Energy, Republic of Korea) (grant no. 20138520011120) 


\section{References}

[1] W.N. Shafarman, S. Siebentritt, L. Stolt, $\mathrm{Cu}(\mathrm{In}, \mathrm{Ga}) \mathrm{Se}_{2}$ Solar Cells, in: A. Luque, S. Hegedus (Eds.) Handbook of Photovoltaic Science and Engineering, John Wiley \& Sons, Chichester, West Sussex, UK, 2010, pp. 546 - 599.

[2] P. Jackson, R. Wuerz, D. Hariskos, E. Lotter, W. Witte, M. Powalla, Effects of heavy alkali elements in $\mathrm{Cu}(\mathrm{In}, \mathrm{Ga}) \mathrm{Se}_{2}$ solar cells with efficiencies up to $22.6 \%$, physica status solidi (RRL) - Rapid Research Letters, (2016) 10.1002/pssr.201600199.

[3] P. Jackson, D. Hariskos, E. Lotter, S. Paetel, R. Wuerz, R. Menner, W. Wischmann, M. Powalla, New world record efficiency for $\mathrm{Cu}(\mathrm{In}, \mathrm{Ga}) \mathrm{Se}_{2}$ thin-film solar cells beyond 20\%, Progress in Photovoltaics: Research and Applications, 19 (2011) 894-897.

[4] M. Yuan, D.B. Mitzi, O. Gunawan, A.J. Kellock, S.J. Chey, V.R. Deline, Antimony assisted lowtemperature processing of $\mathrm{CuIn}_{1-\mathrm{x}} \mathrm{Ga}_{\mathrm{x}} \mathrm{Se}_{2-\mathrm{y}} \mathrm{S}_{\mathrm{y}}$ solar cells, Thin Solid Films, 519 (2010) 852-856.

[5] K. Kim, G.M. Hanket, T. Huynh, W.N. Shafarman, Three-step $\mathrm{H}_{2} \mathrm{Se} / \mathrm{Ar} / \mathrm{H}_{2} \mathrm{~S}$ reaction of Cu-In-Ga precursors for controlled composition and adhesion of $\mathrm{Cu}(\mathrm{In}, \mathrm{Ga})(\mathrm{Se}, \mathrm{S})_{2}$ thin films, Journal of Applied Physics, 111 (2012) 083710.

[6] D.H. Shin, J.H. Kim, Y.M. Shin, K.H. Yoon, E.A. Al-Ammar, B.T. Ahn, Improvement of the cell performance in the $\mathrm{ZnS} / \mathrm{Cu}(\mathrm{In}, \mathrm{Ga}) \mathrm{Se}_{2}$ solar cells by the sputter deposition of a bilayer $\mathrm{ZnO}: \mathrm{Al}$ film, Progress in Photovoltaics: Research and Applications, 21 (2013) 217-225.

[7] O. Lundberg, M. Bodegård, J. Malmström, L. Stolt, Influence of the $\mathrm{Cu}(\mathrm{In}, \mathrm{Ga}) \mathrm{Se}_{2}$ thickness and $\mathrm{Ga}$ grading on solar cell performance, Progress in Photovoltaics: Research and Applications, 11 (2003) 77-88. [8] W.N. Shafarman, R.S. Huang, S.H. Stephens, Characterization of $\mathrm{Cu}(\mathrm{InGa}) \mathrm{Se}_{2}$ solar cells using etched absorber layers, in: Conference Record of IEEE 4th World Conference on Photovoltaic Energy Conversion, 2006, pp. 420-423.

[9] K. Kim, H. Park, W.K. Kim, G.M. Hanket, W.N. Shafarman, Effect of reduced Cu(InGa)(SeS $)_{2}$ thickness uing three-Step $\mathrm{H}_{2} \mathrm{Se} / \mathrm{Ar} / \mathrm{H}_{2} \mathrm{~S}$ reaction of $\mathrm{Cu}-\mathrm{In}-\mathrm{Ga}$ metal precursor, IEEE Journal of Photovoltaics, 3 (2013) 446-450.

[10] N.-M. Park, H.S. Lee, D.-H. Cho, Y.-D. Chung, K.-H. Kim, K.-S. Lee, J. Kim, Effect of Se flux on $\mathrm{CuIn}_{1-\mathrm{x}} \mathrm{Ga}_{\mathrm{x}} \mathrm{Se}_{2}$ film in reactive sputtering process, Progress in Photovoltaics: Research and Applications, 20 (2012) 899-903.

[11] T. Nakada, Y. Hirabayashi, T. Tokado, D. Ohmori, T. Mise, Novel device structure for Cu(In,Ga)Se thin film solar cells using transparent conducting oxide back and front contacts, Solar Energy, 77 (2004) 739-747.

[12] J.K. Larsen, H. Simchi, P. Xin, K. Kim, W.N. Shafarman, Backwall superstrate configuration for ultrathin $\mathrm{Cu}(\mathrm{In}, \mathrm{Ga}) \mathrm{Se}_{2}$ solar cells, Applied Physics Letters, 104 (2014) 033901. 
[13] K. Zweibel, Issues in thin film PV manufacturing cost reduction, Solar Energy Materials and Solar Cells, 59 (1999) 1-18.

[14] F.J. Haug, H. Zogg, A.N. Tiwari, 11\% efficiency on CIGS superstrate solar cells without sodium precursor, in: Conference Record of the 29th IEEE Photovoltaic Specialists Conference 2002, pp. 728731.

[15] T. Negami, M. Nishitani, M. Ikeda, T. Wada, Preparation of CuInSe ${ }_{2}$ films on large grain CdS films for superstrate-type solar cells, Solar Energy Materials and Solar Cells, 35 (1994) 215-222.

[16] T. Nakada, T. Kume, A. Kunioka, Superstrate-type CuInSe ${ }_{2}$-based thin film solar cells by a lowtemperature process using sodium compounds, Solar Energy Materials and Solar Cells, 50 (1998) 97-103. [17] T. Yoshida, R.W. Birkmire, Fabrication of $\mathrm{CuInSe}_{2}$ solar cells in a superstrate configuration, in: Conference Record of 11th European Photovoltaic Solar Energy Conference, Montreux, Switzerland, 1992, pp. 811-814.

[18] M.D. Irwin, D.B. Buchholz, A.W. Hains, R.P.H. Chang, T.J. Marks, P-Type semiconducting nickel oxide as an efficiency-enhancing anode interfacial layer in polymer bulk-heterojunction solar cells, Proceedings of the National Academy of Sciences, 105 (2008) 2783-2787.

[19] A. Kyaw, X. Sun, C. Jiang, G. Lo, D. Zhao, D. Kwong, An inverted organic solar cell employing a sol-gel derived $\mathrm{ZnO}$ electron selective layer and thermal evaporated $\mathrm{MoO}_{3}$ hole selective layer, Appl. Phys. Lett, 93 (2008) 221107.

[20] H. Simchi, B.E. McCandless, T. Meng, J.H. Boyle, W.N. Shafarman, Characterization of reactively sputtered molybdenum oxide films for solar cell application, Journal of Applied Physics, 114 (2013) 013503.

[21] K.-S. Chen, J.-F. Salinas, H.-L. Yip, L. Huo, J. Hou, A.K.Y. Jen, Semi-transparent polymer solar cells with $6 \%$ PCE, $25 \%$ average visible transmittance and a color rendering index close to 100 for power generating window applications, Energy \& Environmental Science, 5 (2012) 9551-9557.

[22] N. Oka, H. Watanabe, Y. Sato, H. Yamaguchi, N. Ito, H. Tsuji, Y. Shigesato, Study on $\mathrm{MoO}_{3-\mathrm{x}}$ films deposited by reactive sputtering for organic light-emitting diodes, J. Vac. Sci. Technol. A, 28 (2010) 886889.

[23] M. Lu, U. Das, S. Bowden, S. Hegedus, R. Birkmire, Optimization of interdigitated back contact silicon heterojunction solar cells: tailoring hetero-interface band structures while maintaining surface passivation, Progress in Photovoltaics: Research and Applications, 19 (2011) 326-338.

[24] M. Bär, S. Nishiwaki, L. Weinhardt, S. Pookpanratana, W.N. Shafarman, C. Heske, Electronic level alignment at the deeply buried absorber/Mo interface in chalcopyrite-based thin film solar cells, Applied Physics Letters, 93 (2008) 042110. 
[25] D. Abou-Ras, G. Kostorz, D. Bremaud, M. Kälin, F.V. Kurdesau, A.N. Tiwari, M. Döbeli, Formation and characterisation of $\mathrm{MoSe}_{2}$ for $\mathrm{Cu}(\mathrm{In}, \mathrm{Ga}) \mathrm{Se}_{2}$ based solar cells, Thin Solid Films, 480-481 (2005) 433438.

[26] M. Gloeckler, Ph.D. Dissertation: Numerical Modeling of CIGS Solar Cells: Definition of the Baseline and Explanation of Superposition Failure, in: Department of Physics, Colorado State University, Fort Collins, CO 80523, 2003.

[27] N. Hernández-Como, A. Morales-Acevedo, Simulation of hetero-junction silicon solar cells with AMPS-1D, Solar Energy Materials and Solar Cells, 94 (2010) 62-67.

[28] M.N. Islam, A. Pradhan, S. Kumar, Effects of crystallite size distribution on the Raman-scattering profiles of silicon nanostructures, Journal of Applied Physics, 98 (2005) 024309-024306.

[29] E. Bustarret, M.A. Hachicha, M. Brunel, Experimental determination of the nanocrystalline volume fraction in silicon thin films from Raman spectroscopy, Applied Physics Letters, 52 (1988) 1675-1677.

[30] B. Vermang, J.T. Watjen, C. Frisk, V. Fjallstrom, F. Rostvall, M. Edoff, P. Salomé, J. Borme, N. Nicoara, S. Sadewasser, Introduction of Si PERC rear contacting design to boost Efficiency of $\mathrm{Cu}(\mathrm{In}, \mathrm{Ga}) \mathrm{Se}_{2}$ Solar Cells, IEEE Journal of Photovoltaics, 4 (2014) 1644-1649. 


\section{Figure captions}

Fig. 1. (a) J-V charaterstics and (b) exertnal QE curves of cell with $1.9 \mu \mathrm{m}$ - and $0.25 \mu \mathrm{m}$-thick CIGSS films (on Mo).

Fig. 2. J-V characteristics (a) and band diagram (b) of a CIGSS cell on the SLG/ITO substrate.

Fig. 3 Band alignment btween CIGSS and p-i-Si.

Fig. 4. Raman profiles of p-Si/i-Si layer before (a) and after (b) selenization/sulfizaiton reaction. The Raman profile of the $\mathrm{p}-\mathrm{Si} / \mathrm{i}-\mathrm{Si}$ layer after reaction was measured after peeling off the CIGSS film on the p-Si/i-Si layer.

Fig. 5. Schmatic drawing (a), cross-sectional SEM iamge (b) and photo (c) of a bifacial cell with the structure SLG/ITO/p-a-Si/i-a-Si/CIGSS $(0.25 \mu \mathrm{m}) / \mathrm{CdS} / \mathrm{i}-\mathrm{ZnO} / \mathrm{ITO}$.

Fig. 6. J-V characteristics of bi-facial CIGSS cell testing under front-side illumination (a) and back-side illumination (b).

Fig. 7. (a) QE curves of bi-facial CIGSS cell measured with front-side (solid square) and backside (solid circle) illumination. Reflectance curves of each case are also given with the right Y axis. (b) Comparison of QE curves: measured EQE curve with back-side illumination (solid circle) and its redrawn one by removing parasitic absorption in the SLG/ITO/p-Si/i-Si substrate (solid square). Transmittance of the $\mathrm{SLG} / \mathrm{ITO} / \mathrm{p}-\mathrm{Si} / \mathrm{i}-\mathrm{Si}$ substrate (solid triangle) is also given with the right Y-axis.

Fig. 8. J-V curve of back-wall CIGSS cell with an Ag reflector. The inset shows a schematic drawing of a back-wall CIGSS cell with the Ag reflector.

Fig. 9. QE curves of the back-wall CIGSS cell with (solid square) and without light loss (hollow square) from the SLG/ITO/p-Si/i-Si substrate. For reference, the bi-facial CIGSS cell's QE 
results with back-side illumination are also given (external QE curve: solid circle; QE curve without loss from the substrate: hollow circle). 

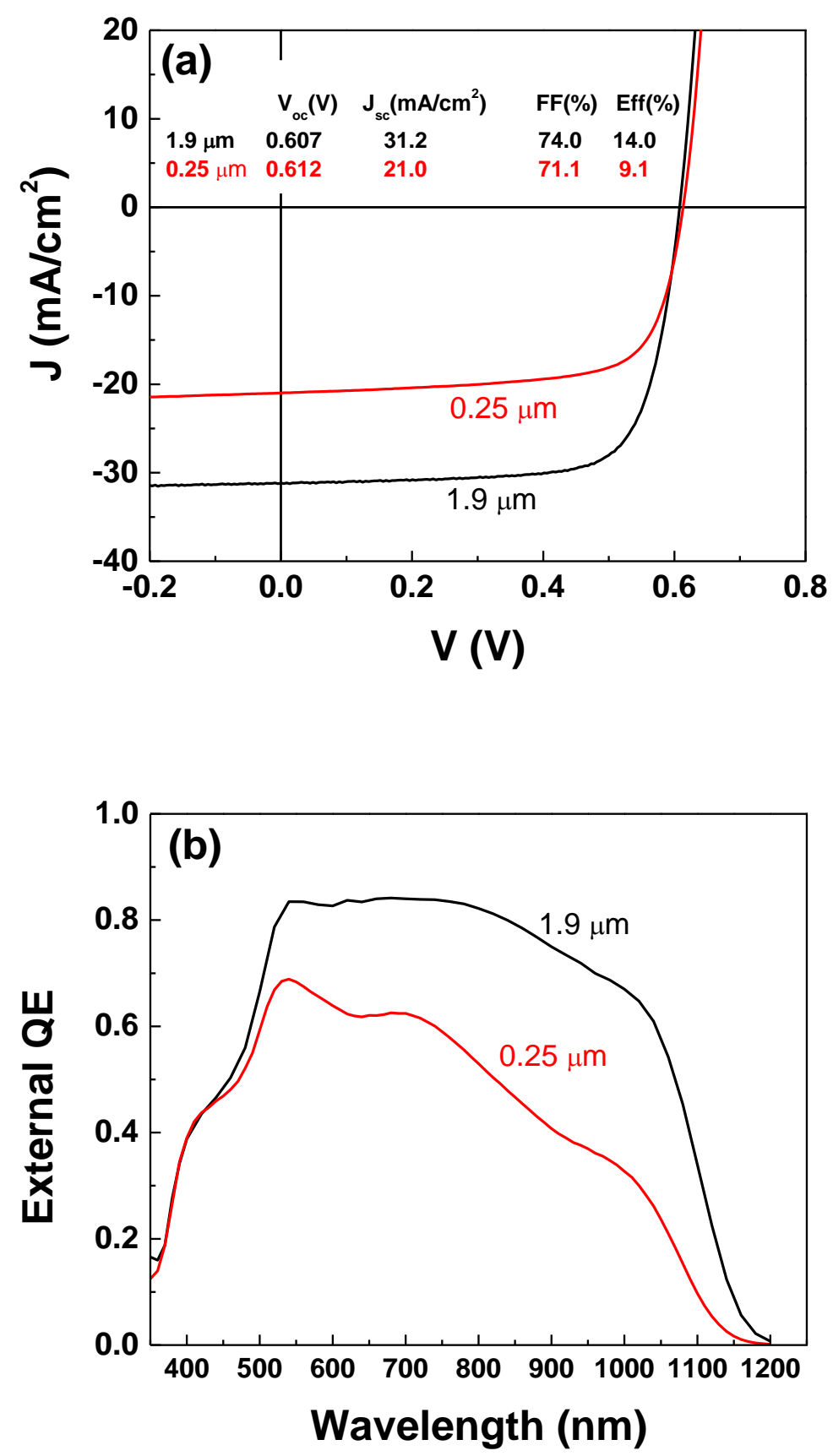

Fig. 1. (a) J-V charaterstics and (b) exertnal QE curves of cell with $1.9 \mu \mathrm{m}$ - and $0.25 \mu \mathrm{m}$-thick CIGSS films (on Mo). 

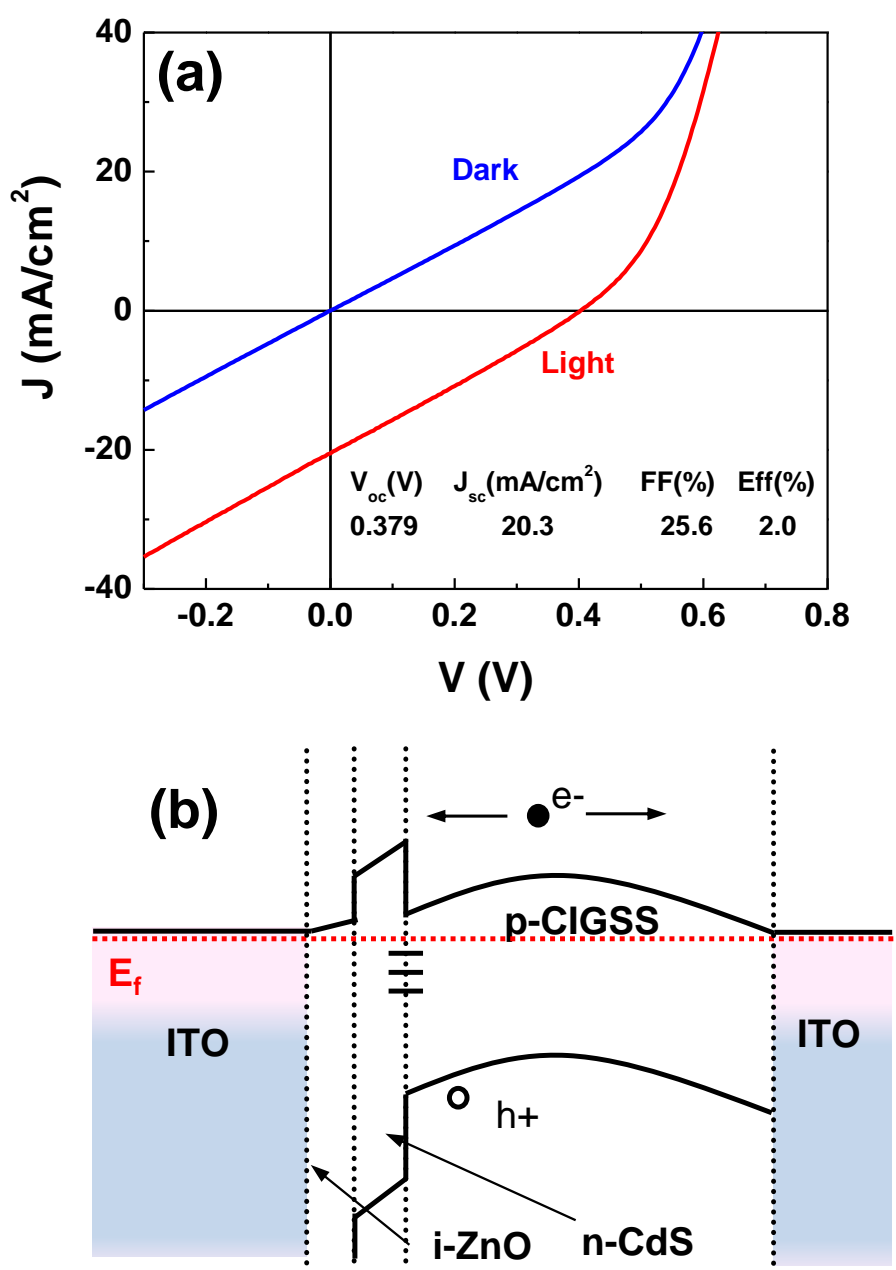

Fig. 2. J-V characteristics (a) and band diagram (b) of a CIGSS cell on the SLG/ITO substrate. 


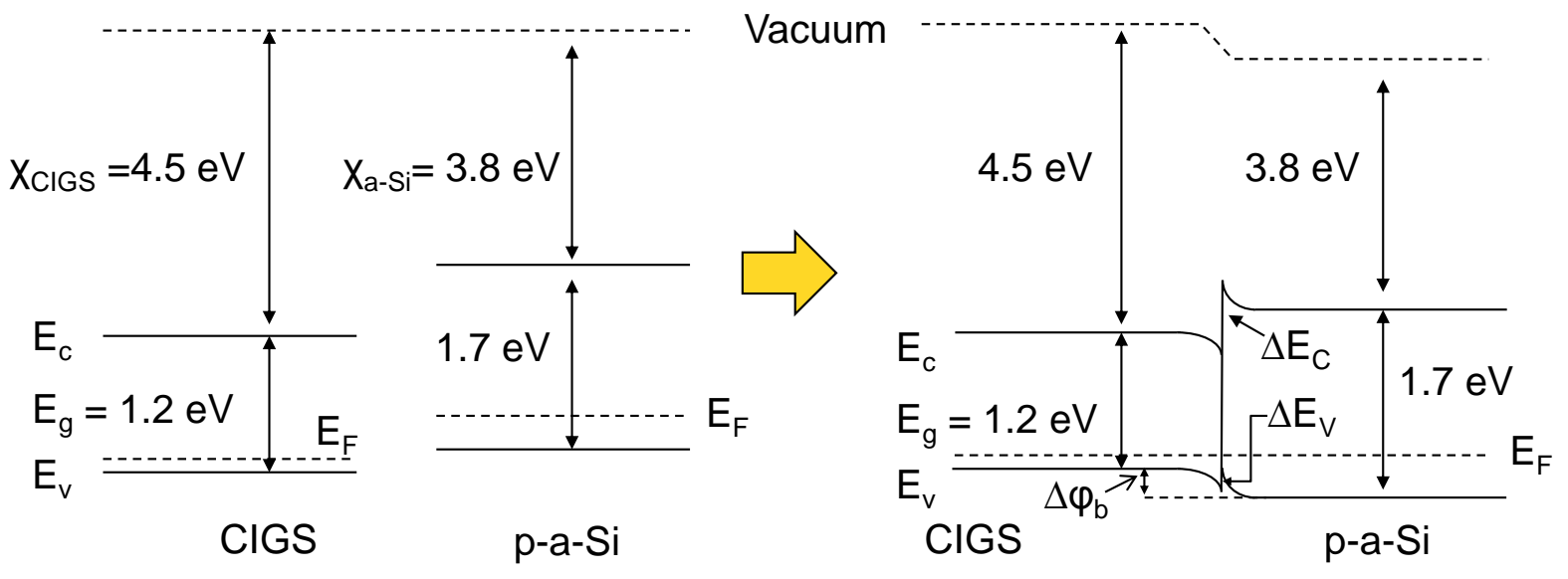

Fig. 3. Band alignment between CIGSS and p-i-Si. 


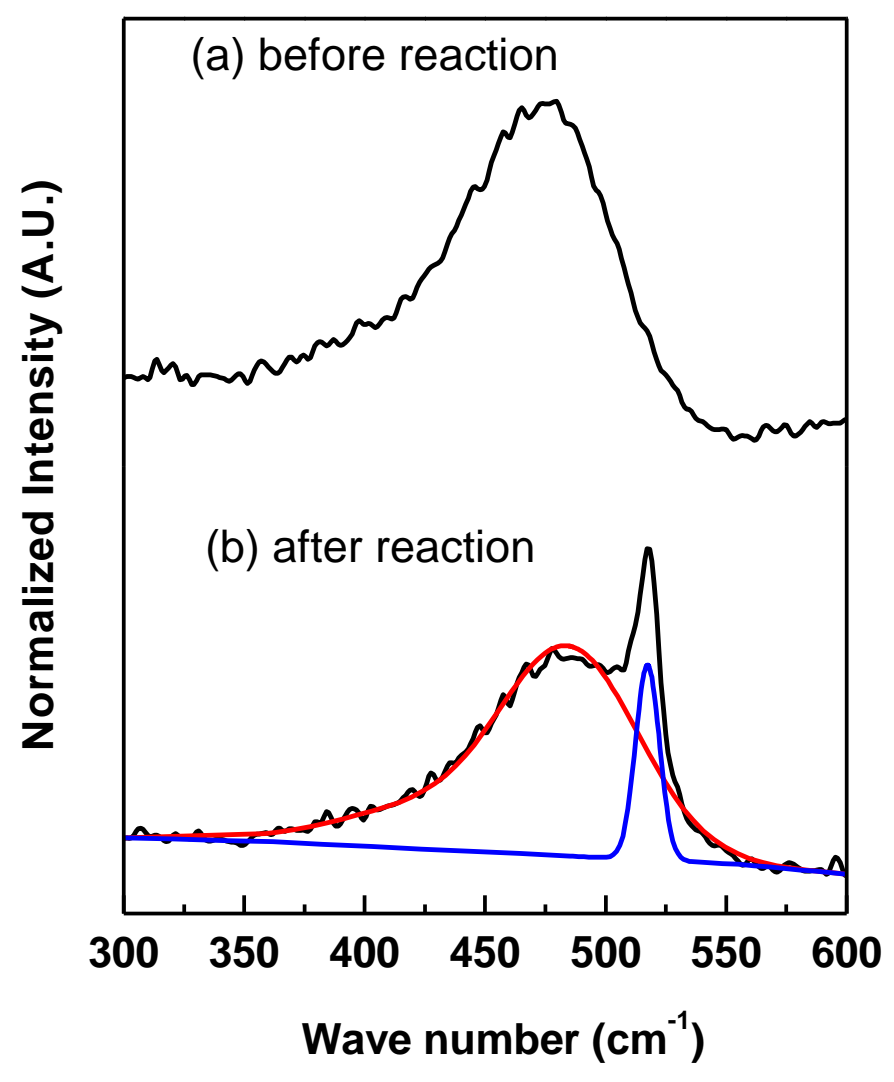

Fig. 4. Raman profiles of p-Si/i-Si layer before (a) and after (b) selenization/sulfizaiton reaction. The Raman profile of the $\mathrm{p}-\mathrm{Si} / \mathrm{i}-\mathrm{Si}$ layer after reaction was measured after peeling off the CIGSS film on the $\mathrm{p}-\mathrm{Si} / \mathrm{i}-\mathrm{Si}$ layer 

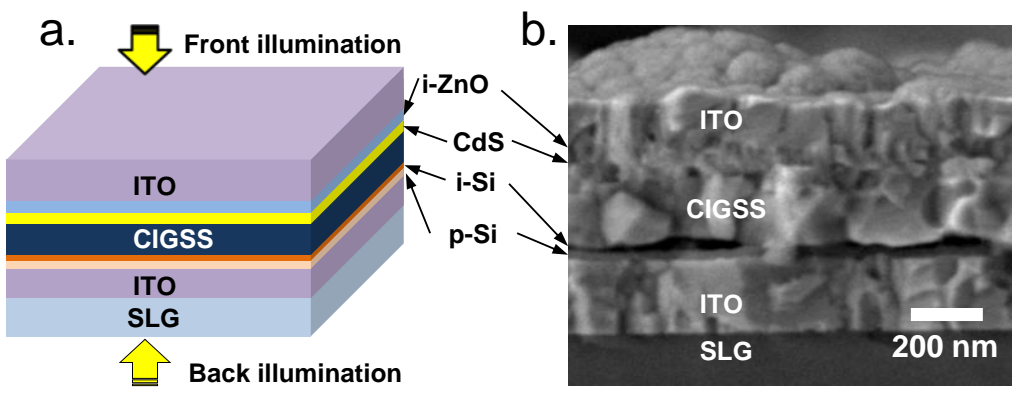

C.

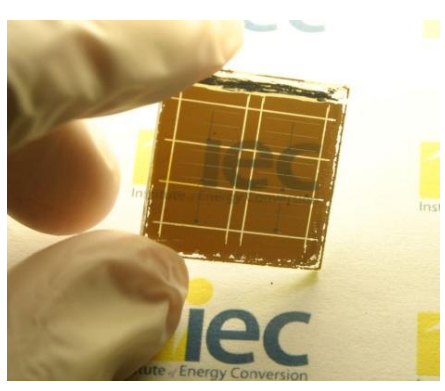

Fig. 5. Schmatic drawing (a), cross-sectional SEM iamge (b) and photo (c) of a bifacial cell with the structure SLG/ITO/p-a-Si/i-a-Si/CIGSS $(0.25 \mu \mathrm{m}) / \mathrm{CdS} / \mathrm{i}-\mathrm{ZnO} / \mathrm{ITO}$. 


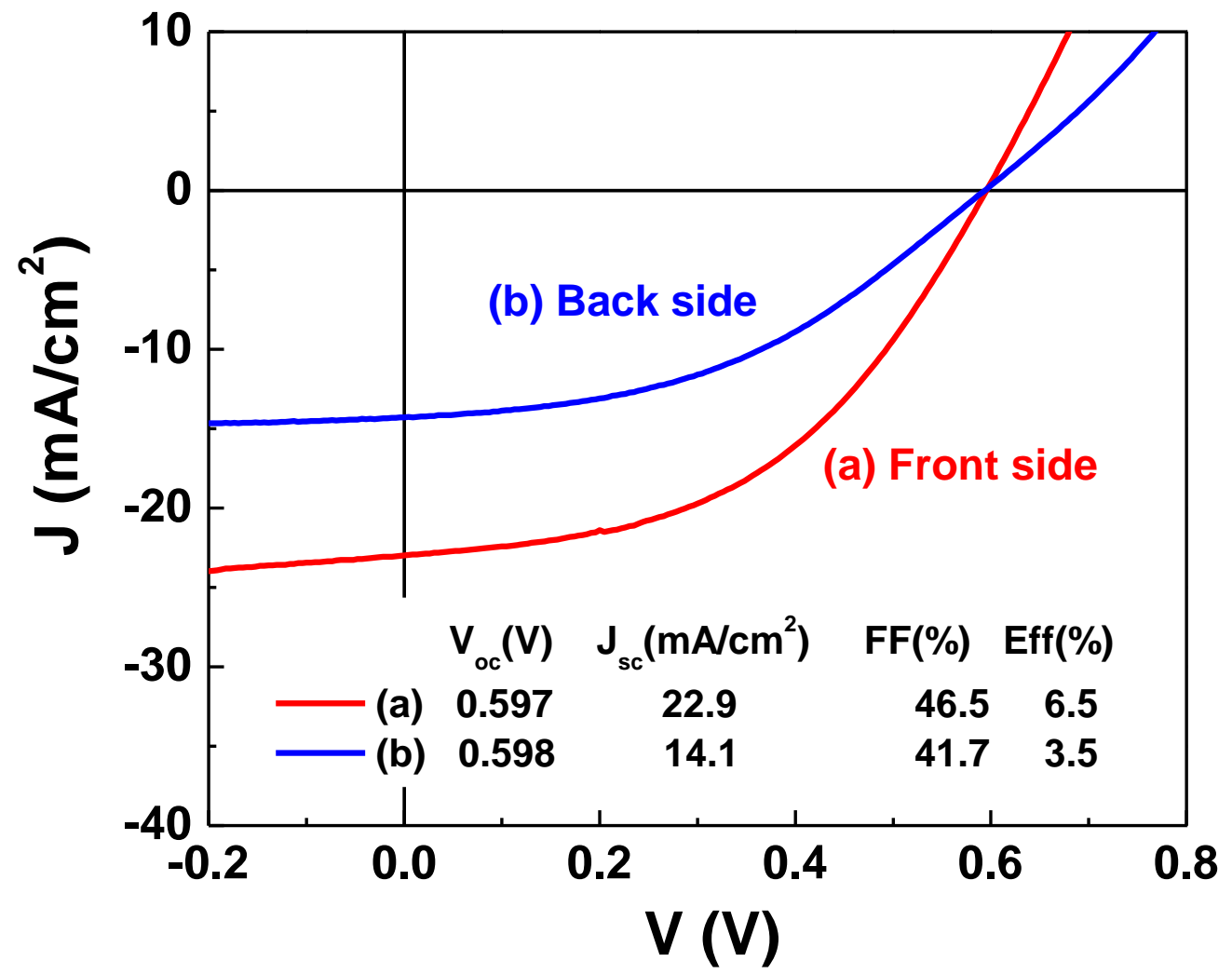

Fig. 6. J-V characteristics of bi-facial CIGSS cell testing under front-side illumination (a) and back-side illumination (b). 

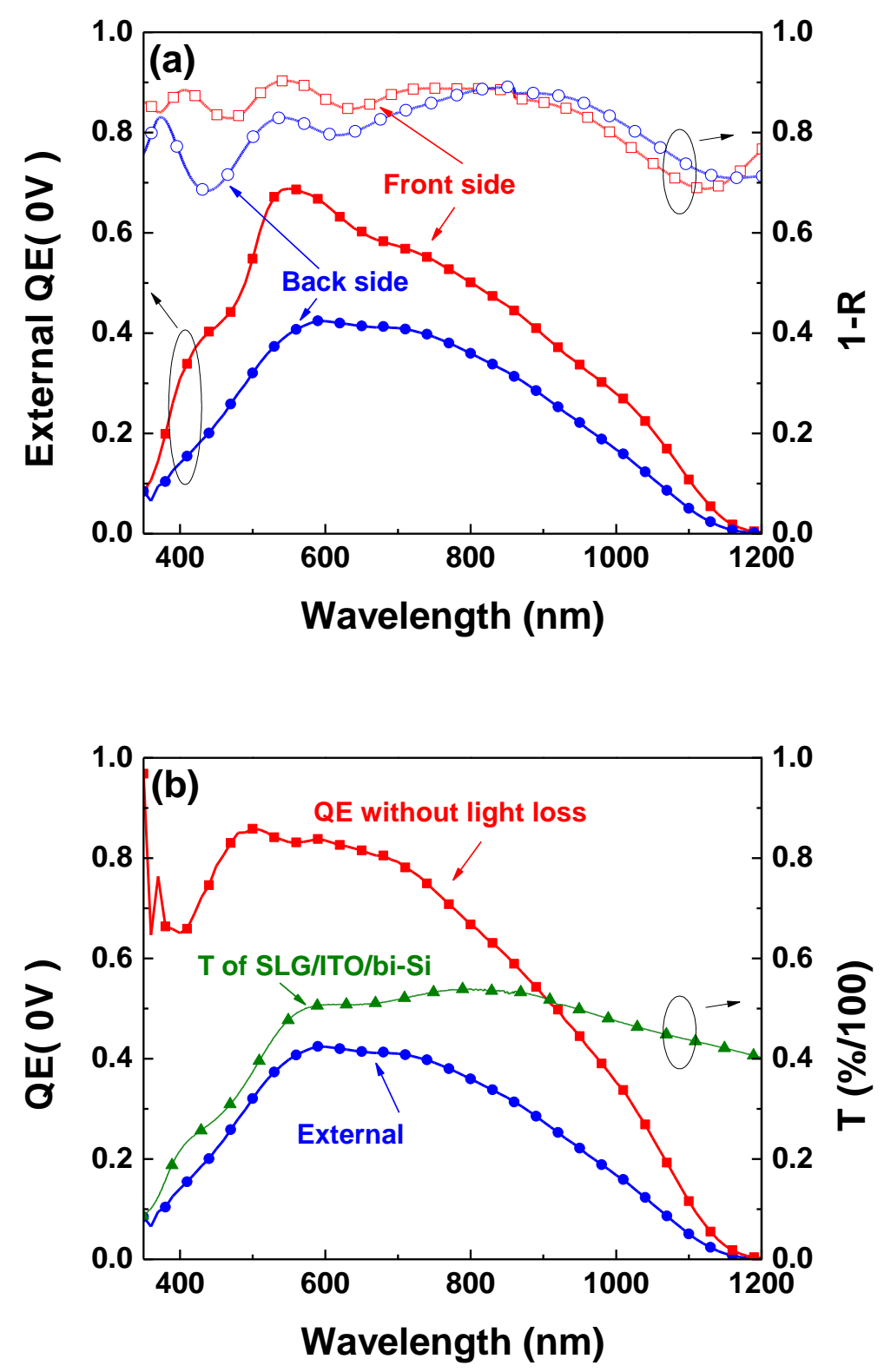

Fig. 7. (a) QE curves of bi-facial CIGSS cell measured with front-side (solid square) and backside (solid circle) illumination. Reflectance curves of each case are also given with the right $\mathrm{Y}$ axis. (b) Comparison of QE curves: measured EQE curve with back-side illumination (solid circle) and its redrawn one by removing parasitic absorption in the SLG/ITO/p-Si/i-Si substrate (solid square). Transmittance of the $\mathrm{SLG} / \mathrm{ITO} / \mathrm{p}-\mathrm{Si} / \mathrm{i}-\mathrm{Si}$ substrate (solid triangle) is also given with the right Y-axis. 


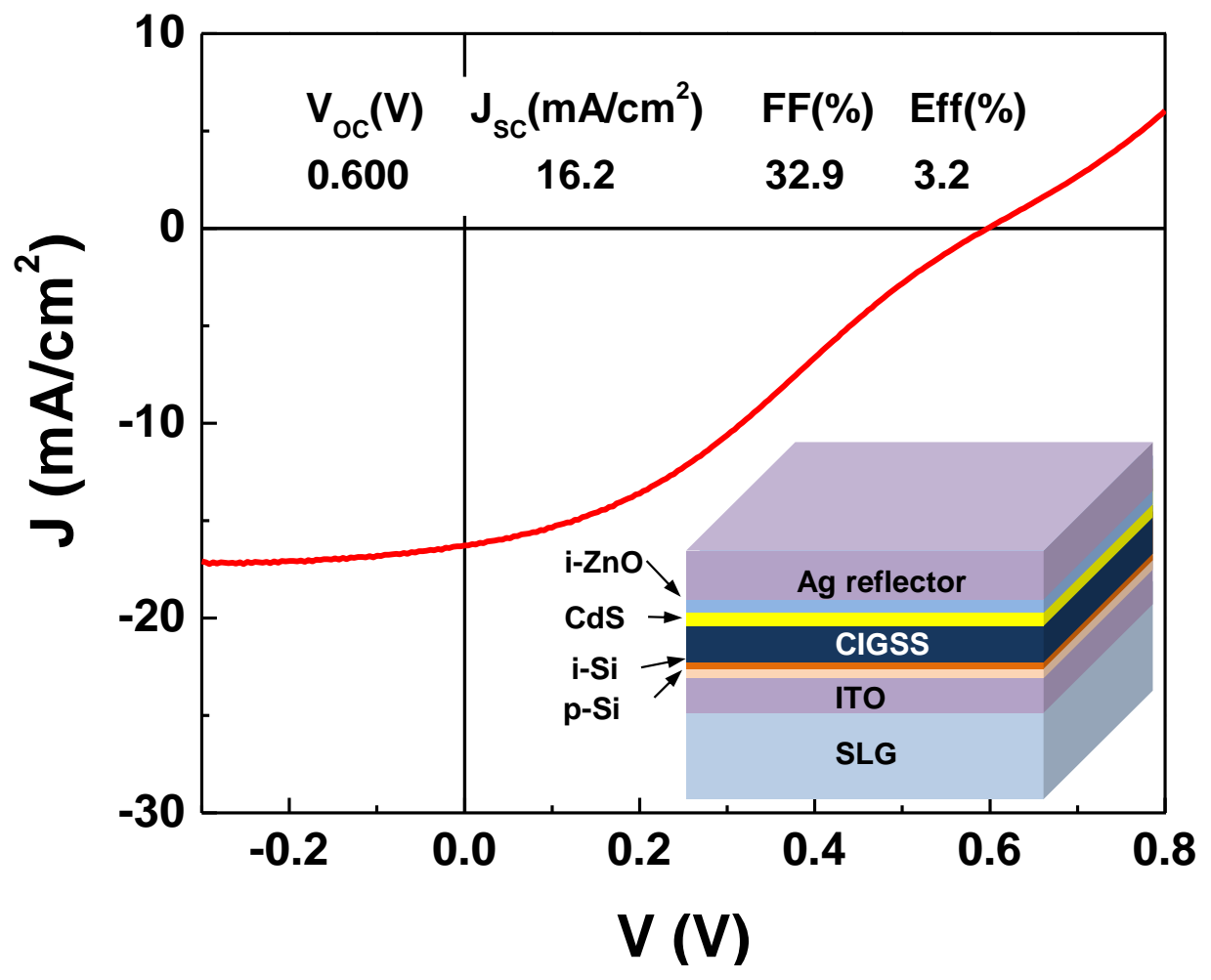

Fig. 8. J-V curve of back-wall CIGSS cell with an Ag reflector. The inset shows a schematic drawing of a back-wall CIGSS cell with the Ag reflector. 


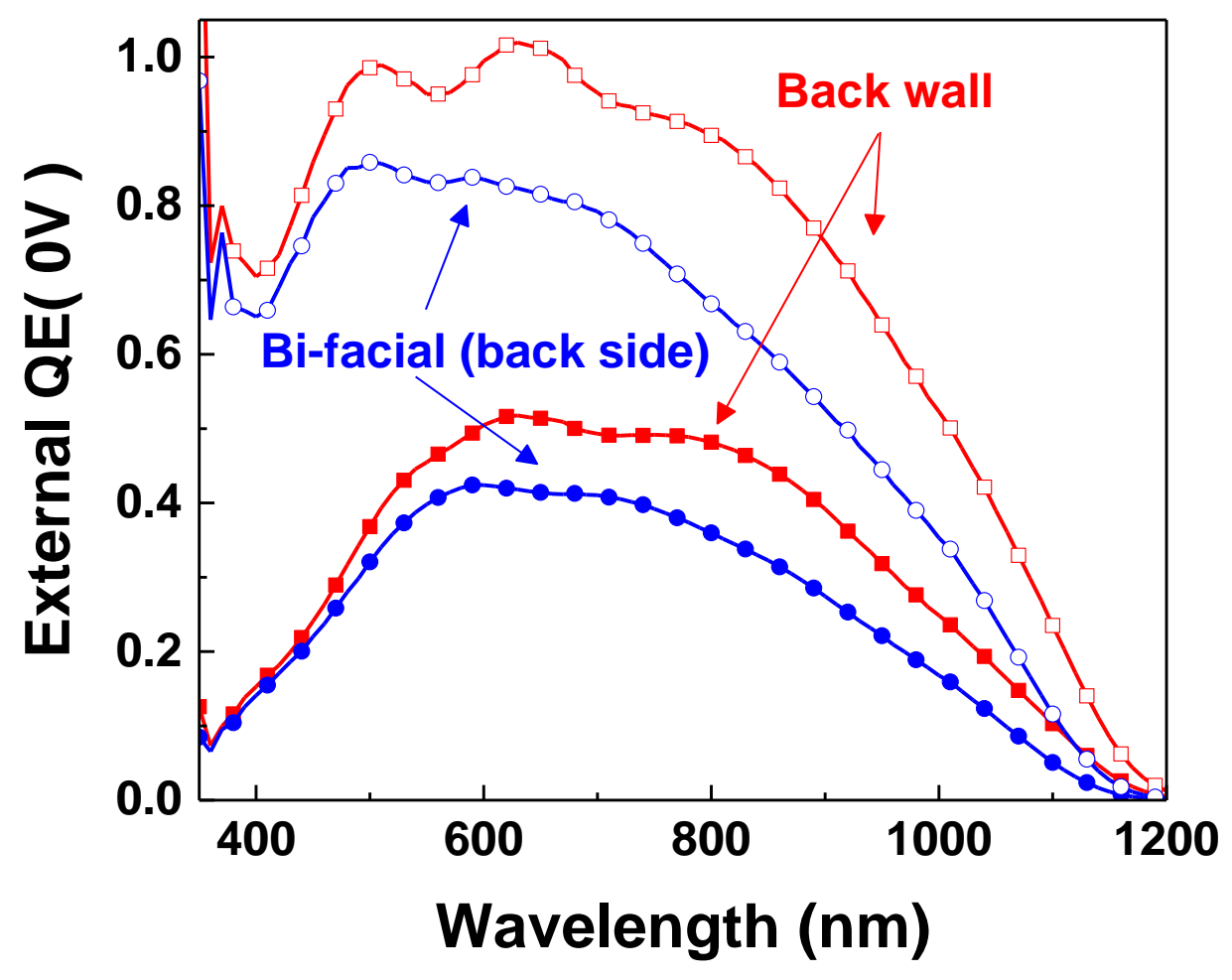

Fig. 9. QE curves of the back-wall CIGSS cell with (solid square) and without light loss (hollow square) from the SLG/ITO/p-Si/i-Si substrate. For reference, the bi-facial CIGSS cell's QE results with back-side illumination are also given (external QE curve: solid circle; QE curve without loss from the substrate: hollow circle). 


\section{Alternative device structures for CIGS-based solar cells with semi- transparent absorbers}

Kihwan Kim ${ }^{1,2}$ and William N. Shafarman ${ }^{2}$

${ }^{1}$ Photovoltaic laboratory, Korea Institute of Energy Research, Daejeon 34129, Republic of Korea

${ }^{2}$ Institute of Energy Conversion, University of Delaware, Newark, DE 19716, USA
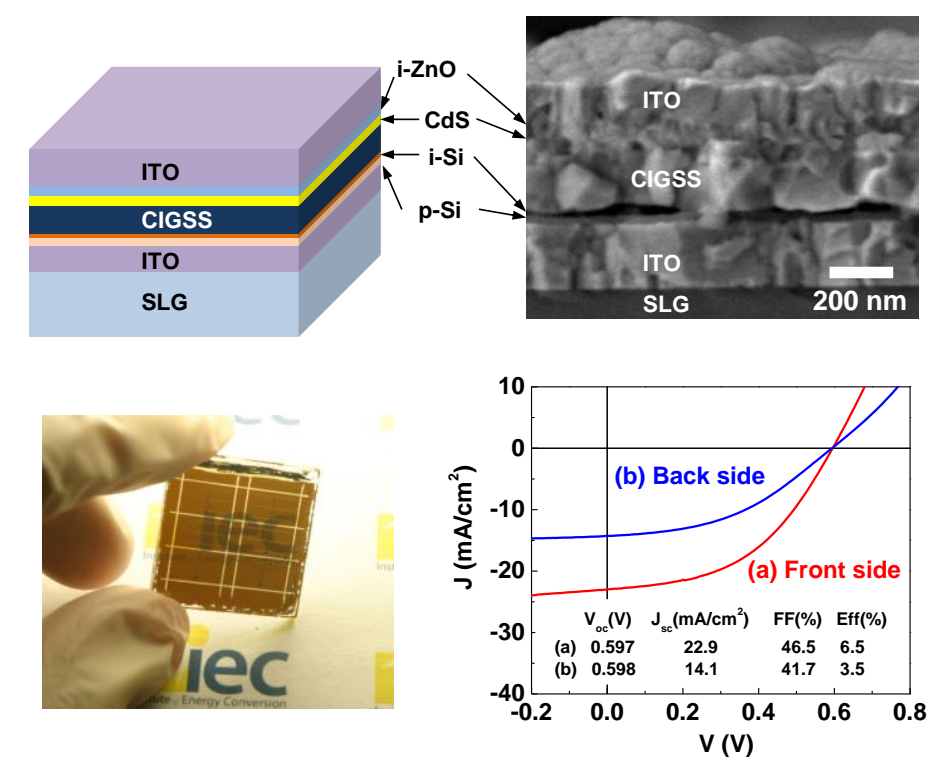

This work explores alternative structures of CIGS-based cells, a bi-facial configuration and a back-wall configuration. In these configurations, ITO back contact and semi-transparent $\mathrm{Cu}(\mathrm{In}, \mathrm{Ga})(\mathrm{Se}, \mathrm{S})_{2}$ absorber are used to enhance current collection from back side illumination. In order to reduce recombination at the interface between ITO back contact and $\mathrm{Cu}(\mathrm{In}, \mathrm{Ga})(\mathrm{Se}, \mathrm{S})_{2}$ absorber, a p-type amorphous $\mathrm{Si} /$ intrinsic amorphous $\mathrm{Si}$ bi-layer was formed on the ITO back contact prior to the absorber layer formation. 